\title{
TERATOGENICITY TESTING OF BI 58 EC (38\% DIMETHOATE) IN CHICKEN EMBRYOS WITH SPECIAL RESPECT TO DEGRADATION OF THE ACTIVE INGREDIENT
}

\author{
L. VÁRNAGY ${ }^{1 *}$, P. BUdAI $^{1}$, Erzsébet MOLNÁR $^{1}$, MRS I. FÜZESI $^{2}$ and T. FÁNCSI ${ }^{3}$ \\ ${ }^{1}$ Department of Zoology and Toxicology, Institute of Animal Science, Georgikon Faculty \\ of Agriculture, University of Veszprém, H-8361 Keszthely, P.O. Box 71, Hungary; \\ ${ }^{2}$ Plant Health and Soil Conservation Station of Zala County, Zalaegerszeg, Hungary; \\ ${ }^{3}$ Department of Anatomy and Histology, Faculty of Veterinary Science, Szent István \\ University, Budapest, Hungary
}

(Received May 22, 2000; accepted February 8, 2001)

The insecticide formulation BI 58 EC was tested for teratogenicity in chicken embryos, with particular reference to degradation of the active ingredient (dimethoate) after the treatment of embryonated eggs. The pesticide was diluted in water to a concentration level of $0.8 \%$, and the emulsion was injected into the air space in a volume of $0.1 \mathrm{ml} / \mathrm{egg}$, or hen's eggs were treated by the immersion technique. Residues of dimethoate were measured in the samples on days 13, 15 and 19 of the incubation of chicken embryos, and morphological examinations were performed simultaneously. Analytical chemistry data indicated a slower degradation of dimethoate in embryos after the immersion of eggs, and cyllosis was remarkable in this group among the sporadic developmental anomalies. The liver tissues of both treated groups exhibited severe fatty infiltration.

Key words: Teratology, pesticide, chick, dimethoate, degradation

In the past four decades the range and use of chemicals increased all over the world. In agriculture, chemicalisation has resulted in a wide-ranging application of xenobiotics. Previous studies proved that the macroscopic and/or microscopic adverse effects of organophosphorous pesticides in avian embryos could cause typical malformations: generally cervical lordosis and scoliosis, cyllosis and sporadic thoraco-gastroschisis (Yamada, 1972; Meiniel and AntissierVavarro, 1980; Várnagy et al., 1982; Hoffman and Albers, 1984; Kumar and Devi, 1992; Várnagy, 1995).

These macroscopic cervical malformations were attributed to hypoplasia (Meiniel, 1977a; Hoffman and Albers, 1984; Kumar and Devi, 1992) or atrophy (Várnagy et al., 1982).

*E-mail: H9650var@ella.hu; Fax: +36 (83) 315105 
The teratogenicity testing of agrochemicals (e.g. pesticides) on birds for registration purposes has been conducted in Hungary by ecotoxicological screening methods since 1988.

The objective of this work was to study the relationship between the morphological changes mentioned above and the degradation of the active ingredient in the developing chicken embryo.

\section{Materials and methods}

BI 58 EC (active ingredient: 38\% dimethoate, Chemie AG, Bitterfeld, GFR) was used. Fertile eggs were collected from hens of the Shaver Starcross 288 or Ross 308 breeds. The experimental design, the body weights, the number of embryos, the mortality rate and the deformities found are presented in Tables 1 and 2 .

Table 1

Experimental data on the teratogenicity of BI $58 \mathrm{EC}$ in chicken (injection treatment)

\begin{tabular}{|c|c|c|c|c|}
\hline \multirow{3}{*}{$\begin{array}{c}\text { Concentration } \\
(\%)\end{array}$} & \multirow{3}{*}{$\begin{array}{c}\text { Embryo weight (g) } \\
\text { Mean } \pm \text { S.D. } \\
\text { (incubation day) }\end{array}$} & \multirow{3}{*}{$\begin{array}{l}\text { No. of } \\
\text { live/dead } \\
\text { embryos }\end{array}$} & Mortality \% & \multirow{3}{*}{$\begin{array}{c}\text { No. of } \\
\text { deformed } \\
\text { embryos }\end{array}$} \\
\hline & & & before & \\
\hline & & & treatment & \\
\hline
\end{tabular}

Series for analytical chemistry, strain: ROSS 308

\begin{tabular}{lrrrrr}
0.0 & $13.87 \pm 0.65(15)$ & $3 / 1$ & 0.0 & 25.0 & - \\
0.8 & $21.59 \pm 4.24(19)$ & $13 / 1$ & 0.0 & 7.1 & $2^{\mathrm{a}}$ \\
0.8 & $13.29 \pm 1.94(15)$ & $13 / 0$ & 0.0 & 0.0 & - \\
0.8 & $9.99 \pm 1.27(13)$ & $15 / 0$ & 0.0 & 0.0 & - \\
\hline
\end{tabular}

Series for morphological examination, strain: Shaver Starcross 288

\begin{tabular}{lrrrrr}
0.0 & $24.76 \pm 2.71(19)$ & $12 / 3$ & 13.3 & 6.7 & $1^{\mathrm{a}}$ \\
0.8 & $23.96 \pm 1.92(19)$ & $9 / 1$ & 0.0 & 10.0 & 0 \\
0.0 & $9.24 \pm 1.44(15)$ & $18 / 2$ & 0.0 & 10.0 & - \\
0.8 & $9.88 \pm 1.11(15)$ & $13 / 2$ & 0.0 & 13.3 & - \\
0.0 & $4.31 \pm 0.58(13)$ & $20 / 0$ & 0.0 & 0.0 & $1^{\mathrm{b}}$ \\
0.8 & $4.31 \pm 0.57(13)$ & $12 / 2$ & 0.0 & 14.3 & - \\
\hline
\end{tabular}

$\mathrm{a}=$ cyllosis; $\mathrm{b}=$ general oedema

In accordance with the international practice, two methods of application were used: (1) The pesticide formulation was injected $(0.1 \mathrm{ml} / \mathrm{egg})$ as aqueous emulsion $(0.8 \%)$ into the air space of the egg on the 12th day of incubation. On the day of treatment all eggs were candled, and infertile and dead ones were discarded. The test material was mixed in distilled water at room temperature. Con- 
trol eggs were injected in a similar manner with distilled water. Before the single injection the calcic egg-shell was bored through, then after the treatment it was sealed with paraffin wax (Masayoshi et al., 1980). (2) In the other series the immersion technique was applied on day 12 of the incubation period. The hen's eggs were immersed in the appropriate emulsion of the test substance $(0.8 \%)$ while the control eggs in distilled water, for $30 \mathrm{~min}$ at $35-37^{\circ} \mathrm{C}$, and then they were placed back in the incubator.

In a previous study the optimal temperature of the immersion fluid was determined (Várnagy et al., 2000).

Table 2

Experimental data on the teratogenicity of BI $58 \mathrm{EC}$ in chicken (immersion treatment)

\begin{tabular}{|c|c|c|c|c|}
\hline \multirow{3}{*}{$\begin{array}{c}\text { Concentration } \\
(\%)\end{array}$} & \multirow{3}{*}{$\begin{array}{c}\text { Embryo weight (g) } \\
\text { Mean } \pm \text { S.D. } \\
\text { (incubation day) }\end{array}$} & \multirow{3}{*}{$\begin{array}{c}\text { No. of } \\
\text { live/dead } \\
\text { embryos }\end{array}$} & Mortality \% & \multirow{3}{*}{$\begin{array}{c}\text { No. of } \\
\text { deformed } \\
\text { embryos }\end{array}$} \\
\hline & & & before & \\
\hline & & & treatment & \\
\hline
\end{tabular}

Series for analytical chemistry, strain: ROSS 308

\begin{tabular}{lrrrrr}
0.0 & $11.36 \pm 1.22(15)$ & $5 / 0$ & 0.0 & 0.0 & - \\
0.8 & $19.55 \pm 3.57(19)$ & $10 / 3$ & 0.0 & 23.1 & $1^{\mathrm{a}}$ \\
0.8 & $15.49 \pm 2.38(15)$ & $11 / 0$ & 0.0 & 0.0 & - \\
0.8 & $8.20 \pm 1.72(13)$ & $12 / 1$ & 0.0 & 7.7 & - \\
\hline
\end{tabular}

Series for morphological examination, strain: Shaver Starcross 288

$\begin{array}{lrrrrr}0.0 & 29.90 \pm 3.42(19) & 10 / 7 & 17.6 & 23.5 & 0 \\ 0.8 & 29.56 \pm 2.47(19) & 9 / 7 & 0.0 & 43.8 & 3^{\mathrm{a}} \\ 0.0 & 8.34 \pm 2.53(15) & 15 / 5 & 0.0 & 25.0 & - \\ 0.8 & 6.94 \pm 1.00(15) & 5 / 10 & 0.0 & 66.6 & - \\ 0.0 & 4.60 \pm 0.81(13) & 20 / 1 & 4.8 & 0.0 & 1^{\mathrm{b}} \\ 0.8 & 4.51 \pm 0.92(13) & 15 / 0 & 0.0 & 0.0 & -\end{array}$

$\mathrm{a}=$ cyllosis $; \mathrm{b}=$ subcutaneous haematoma on the skull

The eggs were placed in a ventilated Ragus (Wien) incubator maintained at $37.5{ }^{\circ} \mathrm{C}$ temperature and $70 \%$ relative humidity, and were rotated three times a day. They were opened for examination on days 13,15 and 19 of the incubation period.

Dimethoate residues were determined analytically from pooled samples, avoiding contamination of the surface. The active ingredient was measured using a Packard 428 type gas chromatograph (GC) with NP detector according to the analytical method HN 14475/44-1988, 'Examination of pesticide residues in foods'. Samples were taken on days 13, 15 or 19 of the incubation period for analytical measurements. 
All embryos were examined for gross lesions and skeletal anomalies. For this purpose the staining technique of Dawson (1926) was used.

For light microscopy, liver, heart and $\mathrm{m}$. longus colli were fixed in $4 \%$ neutral formalin, embedded in paraffin, cut into 5-7 $\mu \mathrm{m}$ thick sagittal sections, and stained with haematoxylin-eosin and oil-red-o (Kiszely and Barka, 1958). Four embryos were sampled in each dose group for histological examination, disregarding the embryos used for analytical measurements on day 19 of incubation.

\section{Results}

\section{Gross examination}

BI 58 EC produced an increase in embryonic mortality after both the immersion and the injection treatment, which was the most expressed on day 15 of the incubation period (Tables 1 and 2).

Embryo weights were similar in the control and treated groups after both treatments. Developmental anomalies occurred sporadically. In one treated group, a remarkable deformation rate was detected only after the immersion treatment of eggs on day 19 of the incubation period (Table 2).

\section{Histological examination}

Light microscopic findings indicated degenerative changes in the liver tissue after both types of treatment. There were many vacuoles in the hepatocytes, and a severe fatty infiltration was seen. No other alterations were detected.

\section{Analytical determination}

The data of analytical chemistry are summarised in Table 3, which shows the quite fast degradation of dimethoate after application by injection. On day 15 of incubation the active substance could not be measured in the chicken embryos.

Table 3

Degradation of dimethoate in chicken embryos after treatment of BI 58 EC

\begin{tabular}{lccc}
\hline \multirow{2}{*}{ Treatment } & \multicolumn{3}{c}{ Sampling days } \\
\cline { 2 - 4 } & 13 & 15 & 19 \\
\cline { 2 - 4 } & Residues $(\mu \mathrm{g} / \mathrm{g})$ & Residues $(\mu \mathrm{g} / \mathrm{g})$ & Residues $(\mu \mathrm{g} / \mathrm{g})$ \\
\hline Control & - & ND & - \\
Injection & 1.20 & ND & ND \\
Control & - & ND & - \\
Immersion & 7.50 & 0.02 & ND \\
\hline
\end{tabular}

$\mathrm{ND}=$ Non-detectable (limit of detection: $0.01 \mu \mathrm{g} / \mathrm{g}$ ) 
Table 3 also demonstrates the dimethoate residues found in chicken embryos after immersion treatment, on days 13 and 15 of incubation. On day 19 of incubation the active ingredient was not detectable in the treated groups.

The concentration of the active ingredient was 6.25 times higher on day 13 of incubation in the samples after immersion treatment than after the injection of dimethoate.

\section{Discussion}

The morphological consequences of the toxic effects of xenobiotics are generally studied and described during ecotoxicological examinations. There are also publications in which the dose-effect is judged on the basis of pathophysiological or morphological changes or the presence of chemical residues in the embryos (Meiniel, 1977b; Várnagy and Füzesi, 1979; Bartalits et al., 1980; Déli et al., 1985; Somlyay and Várnagy, 1989; Várnagy, 1993; Várnagy, 1999).

The appropriate concentration of BI $58 \mathrm{EC}$ had been tested in our laboratory in advance: $0.8 \%$ of the test substance was not teratogenic either after injection or after immersion of the hen's eggs, and this concentration corresponded to that used in the chemical plant protection practice.

In this work, the insecticide formulation BI $58 \mathrm{EC}$ was used to study the relationship between the degradation of active ingredient and the toxic/teratogenic effect exerted on the chicken embryos. The analytical chemistry data showed a quite fast degradation of dimethoate, particularly after injection treatment of eggs on day 12 of incubation. Residues of dimethoate were detected even on day 3 after the immersion of eggs in the test material during the incubation period.

The macroscopic alterations were sporadic and dose-effect dependency was not seen. The elevated rate of cyllosis found on day 19 after the immersion treatment shows that, despite the fast degradation of the active ingredient, macroscopic deformities and pathological changes may develop in some tissues.

The results of macroscopic examinations completed on day 19 of incubation corresponded to the detected concentrations of the active ingredient. On days 13 and 15 of the incubation period, higher dimethoate levels were measured in the embryos after immersion treatment of the eggs than in those treated by the injection procedure. This resulted in an increased incidence rate of cyllosis.

The observed mortality rate was generally higher after the treatments among the Shaver embryos compared to the control. This phenomenon was particularly remarkable after the immersion of eggs. It is probable that this layer strain is more sensitive to the chemical stress in consequence of the smaller body weight of embryos.

The dimethoate concentrations detectable on different days of the incubation period and the changes occurring in the liver tissue did not show any corre- 
lation. The light microscopic examinations demonstrated the same histological picture in all embryos irrespective of the method of treatment and the ingredient level. In spite of its fast degradation, the presence of the active substance gave rise to many vacuoles in the hepatocytes, and severe fatty infiltration was detected after both treatments. The light microscopic results confirm the necessity of using histological methods in avian teratogenicity trials.

\section{Acknowledgement}

The authors wish to acknowledge the technical assistance of Mrs J. Németh, Mrs Cs. Drén and Mrs F. Tóth. This work was supported by a grant from the Hungarian Scientific Research Fund (OTKA), project no. T 025153.

\section{References}

Bartalits, L., Várnagy, L., Székely, L., Imre, R., Hadházy, Á. and Fáncsi, T. (1980): Teratological examination of bird foetuses treated with Parathion $20 \mathrm{WP}$; relationship between morphology and some biochemical parameters. Zbl. Vet. Med. Reihe C 9, 361. (Abstract).

Dawson, A. B. (1926): A note on the staining of the skeleton of cleared specimens with alizarin red S. Stain Techn. 1, 123-124.

Déli, É., Somlyay, I. and Várnagy, L. (1985): Biochemical study of muscle samples from chicken embryos affected by Wofatox 50 EC. Arch. Toxicol. 8, 277-279.

Hoffman, D. J. and Albers, P. H. (1984): Evaluation of potential embryotoxicity and teratogenicity of 42 herbicides, insecticides, and petroleum contaminants to mallard eggs. Arch. Environ. Contam. Toxicol. 13, 15-27.

Kiszely, Gy. and Barka, T. (1958): Practical Microtechnique and Histochemistry (in Hungarian). Medicina Könyvkiadó, Budapest.

Kumar, K. B. S. and Devi, K. S. (1992): Teratogenic effects of methyl-parathion in developing chick embryos. Vet. Hum. Toxicol. 34, 408-410.

Masayoshi, E., Seifert, J., Engel, J. and Casida, J. (1980): Organophosphorous and methylcarbamate teratogens: Structural requirements for inducing embryonic abnormalities in chickens and kyrunenine formidase inhibition in mouse liver. Toxicol. Appl. Pharmacol. 54, 20-30.

Meiniel, R. (1977a): Tératogénie des anomalies axiales induites par un insecticide organophosphoré (le parathion) chez l'embryon d'oiseau. Wilhelm Roux's Arch. 181, 41-63.

Meiniel, R. (1977b): Activité cholinestérasique et expression de la tératogénèse axiale chez l'embryon de caille exposé aux organophosphorés. C. R. Acad. Sc. 285, 401-404.

Meinel, R. and Antissier-Vavarro, Ch. (1980): Teratogenic activity of organophosphate pesticide in chick embryos. Acta Embryol. 1, 33-41.

Somlyay, I. and Várnagy, L. (1989): Changes in blood plasma biochemistry of chicken embryos exposed to various pesticide formulations. Acta Vet. Hung. 37, 179-183.

Várnagy, L. (1993): Biochemical examination of muscle samples from pheasant embryos affected by Wofatox 50 EC (50\% parathion-methyl). Acta Vet. Hung. 41, 409-413.

Várnagy, L. (1995): Teratogenicity testing of pesticides on bird fetuses. Hung. Agr. Res. 2, 30-33.

Várnagy, L. (1999): Degradation of some pesticides in avian embryos. Acta Vet. Hung. 47, 117-122.

Várnagy, L. and Füzesi, I. (1979): Study of permeability of quail eggs by using Methylparathion 18 WP and Parathion 20 WP (in Hungarian). Növényvédelem 9, 385-388. 
Várnagy, L., Imre, R., Fáncsi, T. and Hadházy, Á. (1982): Teratogenic examination of pesticides containing parathion and methylparathion in fowl embryos with special respect to the skeletal system (in Hungarian, with English abstract). Magyar Állatorvosok Lapja 37, 389-397.

Várnagy, L., Molnár, E. and Budai, P. (2000): Effect of the temperature of the immersion fluid on chicken embryos in teratogenicity testing. Acta Vet. Hung. 48, 369-371.

Yamada, A. (1972): Teratogenic effect of organophosphorous insecticides in the chick embryo. II. J. Osaka City Med. Cent. 21, 345-355. 